Fauzi, A.A. $\cdot$ W. Sutari $\cdot$ Nursuhud $\cdot$ S. Mubarok

\title{
Faktor yang mempengaruhi pembungaan pada mangga (Mangifera indica L.)
}

\section{Factors affecting on flowering process of mango (Mangifera indica L.)}

Diterima : 11 Desember 2017/Disetujui : 18 Desember 2017 / Dipublikasikan : 30 Desember 2017

CDepartment of Crop Science, Padjadjaran University

\begin{abstract}
The flowering stage is one important stage in the mango fruit production. This stage is influenced by several environmental and internal factors. In subtropical regions, temperature is one important environmental factor in flowering process. The temperature at $18{ }^{\circ} \mathrm{C}$ during the day and $10{ }^{\circ} \mathrm{C}$ at night are needed to accelerate the flowering process. However, the temperature is not problem in tropic regions due to the temperature between two seasons (dry and wet season) is similar. The important factor that playing in flowering in tropic regions is drought stresses. At flowering stage of mango, the florigenic promoter (FP) is important promoter, while the vegetative promoter (VP) at the vegetative stage. Besides, the phytohormone also has a role in the flowering of mango. Phytohormones that play a role in flowering are auxin, cytokines, ethylene, and gibberellins. Furthermore, the increasing value of the $\mathrm{C} / \mathrm{N}$ ratio could assist flowering initiation in mango plant.
\end{abstract}

Keyword : Flowering, drought, stimulus, phytohormone, carbohydrate

Sari Pada kegiatan produksi mangga, tahap pembungaan pada mangga menjadi salah satu penentu dalam produksi buah mangga. Sehingga tahap pembungaan merupakan bagian penting dalam kegiatan produksi. Pembungaan merupakan tahapan pertama dalam kegiatan produksi buah mangga (Mangifera indica L.) di setiap tahun. Perkembangan tanaman khususnya pembungaan bergantung pada beberapa faktor lingkungan dan internal dari tanaman mangga yang diusahakan. Pada daerah

\footnotetext{
Dikomunikasikan oleh Fiky Yulianto Wicaksono

Fauzi, A.A. ${ }^{1} \cdot$ W. Sutari ${ }^{2}$. Nursuhud ${ }^{2}$. S. Mubarok ${ }^{2}$

${ }^{1}$ Mahasiswa Agroteknologi, Fakultas Pertanian, Unpad

${ }^{2}$ Departeman Budidaya Pertanian, Fakultas Pertanian,

Unpad

Korespondensi : syariful.mubarok@unpad.ac.id
}

subtropis, faktor lingkungan yang mempengaruhi pembungaan adalah faktor suhu. Suhu $18{ }^{\circ} \mathrm{C}$ di siang hari dan $10^{\circ} \mathrm{C}$ di malam hari memicu perkembangan bunga di daerah subtropis. Untuk daerah tropis, faktor suhu tidak sangat mempengaruhi terhadap pembungaan karena perubahan suhu tiap musimnya tidak terlalu tegas. Cekaman kekeringan umumnya dapat memicu pembungaan di daerah tropis. Dalam pembungaan mangga, terdapat adanya rangsangan yang disebut florigenic promoter (FP). Adapun pertumbuhan vegetatif dikendalikan oleh rangsangan induksi berupa vegetative promoter (VP). Fitohormon pun memiliki peran dalam pembungaan mangga. Fitohormon yang berperan dalam pembungaan antara lain auksin, sitokinin, etilen, dan giberelin. Adapun $\mathrm{C} / \mathrm{N}$ rasio yang meningkat menyebabkan terjadinya peningkatan karbohidrat yang tinggi dan mendukung inisiasi bunga. Adanya akumulasi karbohidrat pada bagian tajuk pada masa vegetatif akhir dapat memicu pembungaan.

Kata kunci : Pembungaan, kekeringan, ransangan, fitohormon, karbohidrat

\section{Pendahuluan}

Produksi mangga di Indonesia. Mangga merupakan salah satu komoditas buah-buahan yang cukup penting didunia. Mangga (Mangifera indica) termasuk kedalam keluarga Anacardiaceae (Bally, 2006). Mangga termasuk merupakan komoditas buah-buahan yang paling banyak diproduksi kedua di dunia setelah komoditas pisang. Mangga telah banyak dibudidayakan diberbagai dunia baik di daerah dengan iklim tropis maupun subtropis (Yahia, 2011). 
Di Indonesia, produksi mangga nasional pada tahun 2016 mengalami penurunan dari tahun sebelumnya dengan persentase penurunan produksi sebesar 16,72\% (Badan Pusat Statistik dan Direktorat Jenderal Hortikultura, 2016). Menurut Biswas dan Kumar (2011), hasil yang rendah sangat umum dijumpai akibat dari manajemen budidaya yang buruk. Terlebih pada manajemen pembungaan mangga dilapangan merupakan proses yang paling penting dalam kegiatan produksi mangga.

Pertumbuhan flush pada mangga. Flush merupakan peristiwa pertumbuhan tunas pada ranting. Flush terjadi secara periodik, pada tanaman mangga umumnya flush dapat terjadi 4-5 kali dalam setahun (Davenport dan NúñezEliséa, 1997). Flush pada tanaman mangga terbagi menjadi 3 jenis yakni vegetative flush, reproductive flush, dan flush campuran. Vegetative flush hanya menghasilkan daun baru. Adapun reproductive flush akan memunculkan bunga. Perkembangan reproductive flush ini umumnya karena faktor lingkungan. Selain itu, flush campuran merupakan flush yang memunculkan kombinasi bunga dan daun dalam satu pertumbuhan tunas (Davenport, 2009). Proses pembungaan memiliki kaitan dengan jumlah daun pada beberapa flush berdaun dalam satu ranting di tanaman mangga.

Pada pertumbuhan tanaman mangga terdapat dua tahap penting yakni tahap inisiasi dimana tahap ini merupakan tahap awal pertumbuhan tunas. Selanjutnya, akan terjadi tahap induksi dimana pada tahap ini akan menentukan bentuk dari pertumbuhan tunas baik itu menjadi tunas vegetatif atau generatif (Davenport, 2009).

Menurut Davenport (2009), pembungaan mangga sebagai peristiwa reproduksi yang merupakan kunci utama pada produksi buah. Kondisi pertumbuhan yang baik, waktu dan intensitas berbunga akan sangat menentukan kapan dan bagaimana buah diproduksi pada musim tertentu (Davenport, 2007). Banyak faktor yang mempengaruhi proses pembungaan pada mangga. Perkembangan tanaman khususnya pembungaan bergantung pada beberapa faktor lingkungan dan internal dari tanaman mangga yang diusahakan (Dambreville et al., 2013)

Suhu lingkungan dan stres kekeringan. Faktor lingkungan yang berpengaruh pada umumnya karena faktor suhu atau cekaman lingkungan. Pada daerah subtropis, suhu merupakan faktor lingkungan yang mempengaruhi terhadap proses pembungaan mangga. Suhu $18^{\circ} \mathrm{C}$ di siang hari dan $10^{\circ} \mathrm{C}$ di malam hari memicu perkembangan bunga pada tunas generatif mangga di daerah subtropis (Whiley et al., 1989 dalam Davenport, 2009). Sedangkan pada daerah tropis yang memiliki fluktuasi suhu yang tidak terlalu tegas tiap musimnya, umumnya proses pembungaan terjadi karena adanya cekaman kekeringan (Davenport, 2003). Menurut Ramírez et al. (2014), stres air atau cekaman kekeringan dapat memicu terjadinya induksi pembungaan sesaat sesudah terjadinya inisiasi tunas.

\section{Peran Vegetative Promoter dan Florigenic Promoter}

Florigenic promoter dan vegetative promoter. Dalam tahap induksi pertumbuhan dan perkembangan tajuk ada faktor yang menyebabkan suatu perubahan jenis tajuk baik itu menjadi tajuk vegetatif atau menjadi tajuk generatif. Terjadinya induksi pembungaan diakibatkan karena adanya rangsangan induksi oleh adanya florigenic promoter (FP). Untuk pertumbuhan tajuk vegetatif dikendalikan oleh rangsangan induksi berupa vegetative promoter (VP) (Davenport, 2009). Rangsangan induksi pembungaan ini disintesis pada daun dan ditranslokasikan menuju bagian tunas apikal melalui jaringan floem (Davenport, 2000). Rangsangan induksi pembungaan ini sangat dipengaruhi oleh temperatur. Di daerah subtropis, florigenic promoter dihasilkan pada kondisi dimana temperatur lingkungan cukup rendah $\left(<18^{\circ} \mathrm{C}\right)$ (Ramírez dan Davenport, 2010). Pada daerah tropis yang tidak mengalami perubahan temperatur yang ekstrim, pembungaan karena pengaruh florigenic promoter dihasilkan akibat adanya pengaruh dari usia tanaman (NúñezEliséa dan Davenport, 1995). Pada umur tanaman yang semakin tua menyebabkan rasio FP/VP semakin besar dan hal ini menyebabkan terjadinya pembungaan.

\section{Peran Fitohormon Pada Pembungaan Mangga}

Peran auksin pada pembungaan. Fitohormon pada tanaman mangga pun ikut berperan dalam proses pertumbuhan tajuk. Adapun fitohormon yang ikut berperan dalam pertumbuhan tajuk 
yakni auksin, sitokinin, etilen, dan giberelin (Davenport, 2009). Auksin mempunyai pengaruh dalam inisiasi tajuk, dimana auksin menghambat terjadinya proses inisiasi. Auksin memiliki peran dalam menstimulasi pertumbuhan akar dan membuat dominansi pertumbuhan apikal dengan mencegah pertumbuhan tunas di ketiak daun. Auksin ditransportasikan dari bagian tajuk dan daun tanaman menuju bagian akar (Davenport, 2009). Dalam perannya pada tahap inisiasi, auksin sangat erat kaitannya dengan sitokinin. Rasio konsentrasi auksin dan sitokinin pada tunas yang masuk dalam masa istirahat dapat menentukan terjadinya inisiasi pada tunas tersebut. Pada rasio sitokinin dengan auksin yang cukup tinggi umumnya akan menyebabkan inisiasi pada tunas yang masuk masa istirahat (Davenport, 2000).

Peran sitokinin pada pembungaan. Adapun sitokinin merupakan senyawa yang struktur menyerupai adenin yang mampu memicu pembelahan sel. Sitokinin berfungsi mengatur aktivitas merismatik pada tajuk tanaman. Sitokinin ditranslokasikan melalui jari-ngan xylem dari akar menuju tunas-tunas yang sedang masa istirahat atau dorman (Ravishan-kar, 2014). Kandungan sitokinin dalam tunas pada mangga meningkat saat kondisi lingkungan cukup dingin temperaturnya, dimana kondisi ini merupakan kondisi yang mempengaruhi induksi pembungaan (Davenport, 2009). Bangerth (2006) mengatakan bahwa sitokinin ikut berperan dalam pecahnya masa dorman tunas yang akhirnya menyebabkan proses inisiasi, dimana kondisi lingkungan berada pada temperatur yang cocok untuk pembungaan. Sehingga dapat dikatakan bahwa sitokinin berperan langsung dalam proses pembungaan mangga.

Pengaruh etilen pada pembungaan mangga. Etilen merupakan salah satu hormon yang ikut berperan dalam induksi pembungaan pada tanaman mangga. Menurut Tekchand (1980) dalam Kumar et al. (2014) etilen merupakan faktor utama yang mendukung terjadinya induksi pembungaan di mangga. Hal ini bersesuaian dengan pernyataan Chen (1985) dan Nunez-Elisea (1991) dalam Sandip et al. (2015) bahwa etilen mengambil peran penting dalam induksi pembungaan, hal ini dibuktikan dengan konsentrasi etilen yang tinggi selama masa pembungaan.

Pengaruh giberelin. Hormon giberelin pun ikut serta dalam mempengaruhi induksi pada tanaman mangga. Pada kebanyakan tanaman buah perenial, hormon giberelin memberikan pengaruh untuk menghambat pembungaan (Davenport,2009). Penghambatan pembungaan oleh adanya giberelin ini dipengaruhi konsentrasi giberelin, umur tanaman, dan iklim lingkungan. Konsentrasi giberelin meningkat pada tunas seiring bertambahnya umur dari batang tanaman tersebut. Hal ini sesuai dengan pernyataan Chen (1987) dalam Sandip et al. (2015) yang menemukan bahwa konsentrasi giberelin tertinggi berada pada saat terjadinya diferensiasi pada daun dan konsentrasi giberelin terendah berada pada saat terjadinya masa istirahat pada tajuk, saat munculnya bunga, dan pada saat perkembangan panikel bunga. Menurut Clemens et al. (1996) dalam Rai et al. (2006) bahwa konsentrasi giberelin yang tinggi akan merangsang terjadinya pembelahan dan pemanjangan sel di bagian meristem pucuk sehingga menyebabkan pertumbuhan vegetatif terjadi dan menghambat terjadinya pembungaan. Dari hasil penelitian Rai et al. (2006) pada tanaman manggis, kandungan giberelin yang menurun cukup drastis pada tahap induksi yang merupakan sinyal atau tanda untuk manggis melangsungkan proses pembungaan.

\section{Peran Nutrisi Tanaman Terhadap Pembungaan}

Akumulasi fotosintat saat pembungaan. Nutrisi pada tanaman menjadi faktor yang tidak bisa dikesampingkan dalam mempengaruhi induksi pada mangga. Upreti et al. (2013) menyatakan bahwa rasio $\mathrm{C} / \mathrm{N}$ meningkat di awal induksi pembungaan. Peningkatan rasio $\mathrm{C} / \mathrm{N}$ pada tajuk merupakan konsekuensi dari peningkatan ketersediaan karbohidrat. Kondisi tajuk dengan konsentrasi karbohidrat yang tinggi mendukung terjadinya inisiasi bunga, tentunya dalam kondisi lingkungan yang men-dukung pembungaan. Hal ini mengingat bahwa proses pembungaan membutuhkan energi yang berlimpah. Chako (1991) mengatakan bahwa adanya keterkaitan kandungan karbohidrat pada bagian tajuk dalam proses pembungaan mangga. Status karbohidrat yang meningkat pada kuncup bersamaan dengan adanya stimulus pembungaan akan menghasilkan induksi pembungaan. Selain itu, Widaryanto et al. (2005) mengatakan adanya akumulasi fotosintat yang tinggi di bagian tunas pada masa vegetatif akhir dapat meningkatkan pembentukan kuncup bunga. 
Kandungan nutrisi pun mempengaruhi terhadap ketersediaan florigenic promoter (FP) pada tajuk. Daveport (2009) menyatakan bahwa translokasi florigenic promoter yang aktif dipengaruhi oleh kandungan fotosintat yang tinggi. Hal ini karena florigenic promoter akan ikut larut kedalam fotosintat yang ditranslokasikan juga ke bagian tajuk. Semakin aktif translokasi yang terjadi karena konsentrasi fotosintat tinggi, maka akumulasi florigenic promoter akan cepat terjadi.

\section{Rangkuman}

1. Proses pembungaan mangga dipengaruhi oleh banyak faktor dan setiap faktornya dapat saling mempengaruhi satu sama lain. Terdapat faktor lingkungan dan faktor internal yang berpengaruh dalam memicu pembungaan.

2. Faktor lingkungan yang berpengaruh di daerah subtropis umumnya adalah suhu lingkungan rendah. Sedangkan pada daerah tropis, cekaman kekeringan memicu pembungaan mangga.

3. Faktor internal yang menentukan pembungaan mangga antara lain karena adanya florigenic promoter (FP). Sedangkan faktor yang memicu pertumbuhan vegetatif pada ranting tanaman karena ada pengaruh vegetative promoter (VP). Adapun fitohormon yang ikut berperan dalam pertumbuhan tajuk yakni auksin, sitokinin, etilen, dan giberelin.

\section{Daftar Pustaka}

Badan Pusat Statistik dan Direktorat Jenderal Hortikultura. 2016. Produksi mangga menurut Provinsi, 2012-2016. Dari http://www.pertanian.go.id/ap_pages/m od/datahorti. Diakses pada tanggal 15 Oktober 2017.

Bally, I.S.E. 2006. Specifics profile for pacific island agroforestry (Mangifera indica). Permanent Agriculture Resources. Hawaii.

Bangerth, F. 2006. Flower induction in perennial fruit trees : still an enigma?. ActaHort727 : 176-196

Biswas, B.C. and L. Kumar . 2011. Revolution in mango production success stories of some farmers. The Fertilizer Association of India.
Chako, E.K. 1991. Mango flowering still an enigma. Acta Hort 291: 12-21.

Dambreville, A., P. Lauri, C. Trottier, Y. Guédon, F. Normand. 2013. Deciphering structural and temporal interplays during the architectural development of mango trees. J. of Exp. Botany Vol. 64 (8): 2467-2480

Davenport, T.L. 2000. Processes influencing floral initiation and bloom: the role of phytohormones in a conceptual flowering model. Hort Technology $10: 733-739$.

Davenport, T.L. 2003. Management of flowering in three tropical and subtropical fruit tree species. Hort Science Vol. 38 (7) : 1331-1335.

Davenport, T.L. 2007. Reproductive physiology of mango review. J. Plant Physiol 19 (4) : 363-376.

Davenport, T.L. 2009. Reproductive physiology. In: Litz, R.E, The Mango: Botany Production and Uses, $2^{\text {nd }}$ edition. $C A B$ International, Wallingford, UK. p 97-169

Davenport, T.L. and R. Núñez-Eliséa. 1997. Reproductive physiology, In: Litz, R.E, The Mango: Botany, Production and Uses (Ed). CAB International, New York. p 69-146.

Kumar, M., V. Ponnuswami V, J.P. Kumar and S. Saraswathy. 2014. Influence of season affecting flowering and physiological parameters in mango. Academic Journals Vol. 9(1): 1-6.

Núñez-Eliséa R and T.L. Davenport. 1995. Effect of leaf age, duration of cool temperature treatment, and photoperiod on bud dormancy release and floral initiation in mango. Sci. Hort. 62 : 63-73.

Rai, I.N., R. Poerwanto, L.K. Darusmandan B.S Purwoko. 2006. Perubahan kandungan giberelin dan gula total padafase-fase perkembangan bunga manggis. Hayati Vol. 13 (3): 101-106.

Ramírez, F and T.L Davenport. 2010. Mango (Mangifera indica L.) flowering physiology. Sci. Hort. 126:65-72.

Ramirez F., T.L Davenport, G. Fischer, J.C.A. Pinzon, and C. Ulrichs. 2014. Mango trees have no distinct phenology : the case of mangoes. Scientia Horticulturae 168:258-266

Ravishankar H. 2014. Assimilate partitioning and transformations in some perennial fruit crops with due focus on mango (Mangifera indica L.) : dynamics of shoot-root communication in reproductive phenologyan appraisal. National Seminar-cum- 
Workshop on Physiology of Flowering in Perennial Fruit Crops.

Sandip, M., A.N. Makwana, A.V. Barad, and B.D. Nawade. 2015. Physiology of flowering-the case of mango. International Journal of Applied Research 1(11): 10081012.

Upreti, K.K., Y.T.N. Reddy, S.R.S. Prasad, G.V. Bindu, H.L. Jayaram, and S. Rajan. 2013. Hormonal changes in response to paclobutrazol induced early flowering in mango cv. Totapuri. Scientia Horticulturae 150: 414-418.

Widaryanto, E., C. Udayana, M. Baskara, dan R. Umiarti. 2005. Studi pertumbuhan dan pembungaan tiga jenis Impatiens wallerana pada berbagai tingkat naungan. Fakultas Pertanian Universitas Brawijaya.

Yahia, E.M. 2011. Postharvest biology and technology of tropical and subtropical fruits. Vol. 2 : 494-495. 